\title{
Financial Inclusion in Rural Gujarat: A Review
}

\author{
Shweta Bambuwala ${ }^{1}$, Dr.Sneha Shukla ${ }^{2}$ \\ ${ }^{I}$ (Assistant Professor, Gujarat Technological University, Gujarat, India) \\ ${ }^{2}$ (Associate Professor, N.R.Institute of Business Management, GLS University, Gujarat, India)
}

\begin{abstract}
Implementation of Financial Inclusion Initiatives has come long way in last 10 years starting from many Social Schemes and models to Pradhan Mantri Jan Dhan Yojna, from focusing only on access to financial services till identifying need for Financial literacy, Demonetization and digitalization and few more. India has now focused efforts and has also initiated herculean task of ensuring access through creating reach of financial services with the help of Banks, Financial Institutions and other bodies and ensuring usage by working on financial literacy. Pradhan Mantri Jan Dhan Yojna, BC model and Financial Literacy campaigns have proved their potential to achieve financial inclusion however there are certain barriers which should be strategically taken care of to achieve maximum .This paper is an effort to review past performance of PMJDY, BC model and FLCs and their contribution to achieve financial Inclusion in spite of existing barriers in Rural Gujarat.
\end{abstract}

Keywords: BC Model, FLC, PMJDY, Rural Gujarat

\section{INTRODUCTION}

Financial Inclusion was formaly introduced when a committee under chairmanship of Dr.C.Rangrajan was formed on June 26, 2006 to prepare a strategy of financial inclusion. (Joshi, 2011) Financial Inclusion as defined by RBI is process of ensuring access to appropriate financial products and services needed by vulnerable groups such as weaker sections and low income groups at an affordable cost in fair and transparent manner by mainstream Institutional Players. For any nation irrespective of their development status it is essential to have Financial Inclusivity as it significantly contributes to the GDP and development. In India Since last 10 years various initiatives, Schemes and Programs are introduced by RBI, NABARD and other regulatory bodies to achieve financial Inclusion. Over the years the financial inclusion drive has also focused on critical areas such as financial literacy and employment which must go hand in hand to remove financial Exclusion. Against this background this paper aims to review literature on recent studies carried out on financial inclusion and has made attempt to identify and evaluate status of Rural Gujarat.

\section{OBJECTIVES}

This research paper has mainly following three objectives

1. To understand Financial Inclusion Status in Rural Gujarat

2. To study Pradhan Mantri Jan Dhan Yojna, BC model and Financial Literacy initiatives adopted by banks to achieve financial Inclusion

3. To analyze and study past performance towards reaching out unbanked areas under financial inclusion.

\section{RESEARCH METHODOLOGY}

This study is a descriptive study. For this study data has been collected from secondary Sources such as Research articles, Journals, RBI publication, Gujarat State Government publications, Reports of SLBC Gujarat Dena Bank and Ministry of Gujarat.

\section{LITERATURE REVIEW}

iyer, 2016-17)The Indian government has chosen a unique route-beyond mandates, policies, and PSU banks - for bringing about financial inclusion. Through enabling frameworks such as Pradhan Mantri Jan-Dhan Yojana, RuPay card, and Direct Benefit Transfer scheme, it is ensuring that its financial inclusion drive benefits all strata of the society. With the present government making the right noises to further the economic development agenda, it may be an opportune time to deepen economic progress for its people through more financial inclusion.(S.Trivedi, 2016) This paper suggests that special concentration is required for many states disadvantageous population at an affordable cost. One of the most important facts is that there is a gender based gap in accessing formal financial services, which is represented through World Bank data.(Dr. Gomathy Thyagarajan, 2016)The author criticizes that despite the measures adopted and improved financial access, the 
studies indicate that addressing a need for harmonized action between the banks, the Government and others to make possible access to bank accounts amongst the financially excluded. A more robust set of quantitative and qualitative indicators can be developed to align the indicators with the international standards.(Rachana, 2011) The research paper evaluates satisfaction level of 200 individuals residing in rural area of Gujarat specifically Ambasan, Jotana and Khadalpur villages. It shares the finding such as Rural people having bank accounts are aware about the bank services like cheque book, loans and interest rate, overdraft, credit card/ kisan CC, ATM cards but they don't have that much potential to use the services. The main reason for not opening an account initially is requirement of documents for opening account, the rural people do not have the any document proof and bank has to open the account on the basis of gram panchayat details. Banking procedure, illiteracy and language problem, knowledge of banking services, low income and assets, are other reasons. There is significant impact of occupation of rural public on the amount of loan availed from the bank. People avoid taking loan from banks because of lengthy legal procedure and insistence of collateral.(Prof.Parveen Sultana, 2013) This paper examines to understand whether the present route of implementation of Financial Inclusion is matching with the expected direction of the RBI. To study same on the basis of systematic sampling total sample of 120 comprising of 60 customers of SBI services and 60 non users are selected from four villages from each four zone. The study reveals that banking services launched in their village are useful in general terms but still they are not able to assess in concrete terms whether these services have improved standard of living and overall status in the society.

\section{FINANCIAL INCLUSION IN RURAL GUJARAT: STATUS}

As per Census 2011 Gujarat is having 33 districts and approx. 6.04 crore population out of which $42.6 \%$ Population resides in urban areas where as $57.4 \%$ in rural areas. For Financial inclusions banks are playing important role as has the widest network and reach to ensure inclusion of each and every citizen in financial System. As shown in below mentioned table out of total bank branches existing in Gujarat $42 \%$ branches operates in rural areas compared to $15 \%$ in Metro, $16 \%$ in Urban and $25 \%$ in Semi Urban areas.

Table No.1 Banking At A Glance In Gujarat State - June, 2016

\begin{tabular}{|c|c|c|c|c|}
\hline PARAMETERS & JUNE,2015 & $\begin{array}{l}\text { MARCH, } \\
\mathbf{2 0 1 6}\end{array}$ & JUNE, 2016 & $\begin{array}{l}\text { GROWTH OVER } \\
\text { MARCH 2016 }\end{array}$ \\
\hline $\begin{array}{c}\text { TOTAL No. OF } \\
\text { BRANCHES }\end{array}$ & 8675 & 9017 & 9088 & 71 \\
\hline \multicolumn{5}{|c|}{ CATEGORY OF BRANCHES } \\
\hline RURAL & 3705 & 3718 & 3730 & 12 \\
\hline SEMI - URBAN & 2212 & 2119 & 2128 & 17 \\
\hline URBAN & 1442 & 1211 & 1228 & 33 \\
\hline METRO & 1316 & 1969 & 2002 & 71 \\
\hline TOTAL & 8675 & 9017 & 9088 & 9 \\
\hline
\end{tabular}

(Source: 150 SLBC Gujarat Agenda Note (gujarat, 2016)

This statistics shows that there is increased amount of efforts from government to ensure access to basic financial services exists with existence of bank branches. Further to note that from March 2016 to June 2016 total 71 Branches have been opened in various areas but maximum that is 33 branches have been opened only in metro cities of the states.

Table No.2 ATMs IN GUJARAT STATE-JUNE, 2016

\begin{tabular}{|c|c|c|}
\hline CATEGORY & NO. OF BRANCHES & NO.OF ATMS \\
\hline RURAL & 3730 & 2068 \\
\hline SEMI - URBAN & 2128 & 2651 \\
\hline URBAN & 1228 & 2094 \\
\hline METRO & 2002 & 4139 \\
\hline TOTAL & 9088 & 10952 \\
\hline
\end{tabular}

(Source: 150 SLBC Gujarat Agenda Note (gujarat, 2016)

As per the information provided by SLBC Agenda note, there are 10,952 ATMs in the State of Gujarat as of June, 2016. Although Banks have set up good number of ATMs in Metro, Urban and Semi-urban centers, whereas there is a need to set up more number of ATMs in Rural Areas to help the villagers in availing basic banking services at ease. 


\section{Pradhan Mantri Jan Dhan Yojna (PMJDY)}

Pradhan Mantri Jan Dhan Yojna announced by Modi Government in India is having more than 1 crore beneficiaries out of which around $52 \%$ beneficiary reside in Rural Areas which can be observed from below table. Although PMJDY has been widely criticized for only generating no of accounts opened and not usage of same however it cannot be denied that it has created widest platform for financial Inclusivity.

Table no. 4 Total Beneficiaries of PMJDY as on 10.05.2017 in Gujarat

\begin{tabular}{|l|l|}
\hline Beneficiaries at rural/semi-urban center bank branches & 5608094 \\
\hline Beneficiaries at urban/metro Centre bank branches & 5174948 \\
\hline Total Beneficiaries : & 10783042 \\
\hline Balance in beneficiary accounts (in crore) : 2651.97 \\
\hline
\end{tabular}

(Source: Pradhan Mantri Jan Dhan Yojna website (India)

\section{Bank Mitra / BC (Business Correspondent)}

To reach the Unbanked in remote areas of rural regions where Brick and Mortar model of Bank Branch is not established RBI has introduced a Model of Business Correspondent or Bank Mitra which plays crucial role to ensure availability of financial Services to individuals residing in remote rural areas. One of the successful models of Financial Inclusion also generates employment as any individual above 18 years may become Bank Mitra after clearing screening test. Apart from Individual BCs Institutional BCs are also operational which works in association with banks to ensure availability of financial Services to Targeted Audience.

In Gujarat as per 151 SLBC Agenda Note (Gujarat, 2016) It is Observed that Out of Total 5,860 BCs engaged by the banks in the state only 4,860 were Found Active and equipped with Micro ATM. After the Demonetization there is great need of Improvement in BC Model to carry out transactions in Digital Mode.

\section{Financial Literacy}

To include low income individuals from rural areas financial literacy is must. Financial Literacy .Financial Literacy is prerequisite to achieve financial Inclusion. In Gujarat as per 151 SLBC Agenda Note (Gujarat, 2016) Gujarat state has 49 Financial Literacy centers (FLCs) set up in all Districts by respective lead Banks and RRB sponsored by them out of which 1 FLC is in Metro, 33 in Semi Urban and 15 FLCs are in Urban areas where as no FLC is opened in Rural Areas.FLC centers conduct Financial Literacy camps and other activities to achieve Financial education

\section{CONCLUSIONS}

In spite of various initiatives by many stakeholders there are certain actions needed by Government to improve on this initiatives and to achieve financial Inclusion such as Improvement in BC model considering Demonetization and Digitization movement, special training module to tackle lack of skill in using MicroATMs, Remuneration to ground level functionaries and BCs, Failure proof operational system, lack of usages for bank accounts opened and lack of regional language knowledge of bank staff may create barriers to reach to Vulnerable groups and weaker section of the society. Further Financial literacy is ignored at certain level which is key to ensure financial inclusivity in rural areas and specifically for removing gender bias in financial Inclusion. Thus, Effective and fail safe operational strategy should be developed with usage of accounts opened, innovative products and out of the box service models which may change the horizon of current financial programs.

\section{SCOPE OF FURTHER RESEARCH}

This article reviewed diversified contexts and literature on financial inclusion in Indian perspective, which can be further extended to practical survey by selecting a district or a state, comparison studies and national field survey. Further the scope is limited to Pradhan Mantri Jan Dhan Yojna, BC/BF model and Financial Literacy which can be extended to other initiatives and Schemes.

\section{Journal Papers:}

\section{REFERENCES}

[1]. Joshi, D. P. (2011, June 28). Financial Inclusion and Financial Literacy. BI OECD SEMINAR -Round table updates on financial education and Inclusiopn programmes in India. Reserve Bank Of India presentation.

[2]. iyer, S. (2016-17, Dec-january). on the path to financial Inclusion. India Now business and economy, 03(04). 
[3]. S.Trivedi, A. (2016, july-sept). Reality of Financial Inclusion: India. IJRAR- International Journal of Research and Analytical Reviews, 03(03).

[4]. Dr. Gomathy Thyagarajan, P. J. (2016). Financial Inclusion in India - A Review. 6th International conference on Recent innovations in Science, Engineering and Management (pp. 448-454). Delhi: IIMT college of Engineering.

[5]. Rachana, T. (2011). Financial Inclusion and Performance of Rural Co-operative Banks in Gujarat. Research Journal of Finance and Accounting, 2(06), 40-52.

[6]. Prof.Parveen Sultana, D. D. (2013). A Study on Financial Inclusion of Rural Banking- With Reference to Rural Bangalore. Asia Pacific Journal of Research, 3(special issue X).

[7]. gujarat, S. (2016). 150th SLBC Agenda Note. Ahmedabad: SLBC Dena Bank Gujarat

[8]. Gujarat, S. (2016). Agenda Note 151. Ahmedabad: SLBC Gujarat Dena Bank.

[9]. India, D. o. (n.d.). Pradhanmantri Jan Dhan Yojna. Retrieved may 22, 2017, from https://www.pmjdy.gov.in/statewise-statistics: https://www.pmjdy.gov.in/statewise-statistics

[10]. Demographics Gujarat. (n.d.). Retrieved may 19, 2017, from www.gujaratindia.com. 